\title{
CONSERVATION AND REGULATION: THE NATURAL GAS ALLOCATION POLICY OF THE FEDERAL POWER COMMISSION
}

\author{
H.T. KOPLIN†
}

INTRODUCTION

In the literature of public utility regulation, the problem of determining a rate level fair to consumers and investors alike has received consistent emphasis ${ }^{1}$ to the virtual exclusion of considerations of resource utilization. Little attention has been paid to questions of the extent of the service to be rendered, beyond the usually implicit assumption that extension of service is desirable if consumers are willing to pay for it. ${ }^{2}$ By contrast, the theory of conservation emphasizes the "best use" of optimum allocation, particularly over time, of a natural resource which is scarce relative to demand for it. ${ }^{3}$ Income distribution between consumer and producer is distinctly secondary. ${ }^{4}$

In its regulation of the natural gas industry, the Federal Power Commission has faced a conflict between the usual objectives of public utility regulation and those of conservation-between fair income distribution and wise use of resources. The effects of the Commission's rate policy on conservation have been widely discussed. ${ }^{5}$ But a second area of Commission activity with an equal if not greater significance to conservation has received little notice: the allocation of supplies of natural gas from interstate transmission lines among competing consumer groups. FPC experience illustrates

$\dagger$ Assistant Professor of Economics, University of Oregon. This article is based on sections of the author's unpublished doctoral dissertation, written under Professor A. E. Kahn. Natural Gas Act Certification Policy of the Federal Power Commission (Cornell University Library 1952). See, in particular, cc. I-III, IX, X.

1. See, e.g., Barnes, Economics of Public Utility Regulation cc. 9-17 (1942); Troxel, Economics of Public Utilities cc. 10-19 (1947); Clemens, Economics and Public Utilities cc. 7-15 (1950).

2. Most discussions emphasize quality rather than extent of service. See Barncs, op. cit. supra note 1, cc. VII, XXI; TroXel, op. cit. supra note 1, cc. 3, 21; Clensens, op. cit. supra note 1, c. 4 .

3. See Ciriacy-Wantrup, Resource Conservation (1952); Heady, Econonics of Agricultural Production and Resource Use (1952) ; Pigou, Economics of WetFARE 27-30 (1932); Gray, Economic Possibilities of Conservation, 27 Q. J. EcoN. 499 (1913).

4. But see Ely et al., Foundations of National Prosperity 6 (1918).

5. See, e.g., FPC, Natural Gas Investigation, Report of Commissioncrs Nelson Lee Smith and Harrington Wimberly c. 5 (1948) (hereinafter cited as Surru-Wimues$\mathrm{LX)}$; and id., Report of Commissioners Leland Olds and Claude L. Draper \$\$ IX, X (1948) (hereinafter cited as Olds-Draper); FPC v. Hope Natural Gas Co., 320 U.S. 591 (1944) ; Note, 28 Ind. L.J. 587, 600-16 (1953). 
clearly the basic difficulty of ${ }^{-}$using traditional public utility regulation, designed primarily to prevent monopoly exploitation of the consumer, ${ }^{\mathbb{B}}$ to achieve optimum utilization of a natural resource.

Because natural gas can be transported economically only through pipelines, and because the major producing area is geographically separated from many major consuming areas, the FPC's authority over interstate transmission lines gives it a considerable degree of influence over the quantity and type of natural gas use. ${ }^{7}$ But it must be emphasized at the outset that the Commission has no direct statutory authority to establish a national policy of natural gas utilization. WVith minor changes in wording, the Natural Gas Act ${ }^{8}$ could be used to regulate electricity ${ }^{8}$ or manufactured gas. Nevertheless, through the usual regulatory provisions and particularly through its power to grant, modify, or deny applications for certificates of public convenience and necessity ${ }^{10}$ - a legal prerequisite to the construction or expansion of interstate natural gas transmission facilities-the Commission has evolved a relatively formal set of allocation criteria. This aspect of FPC certification policy will be examined here.

The FPC has by necessity been thrust into the arguments over allocation. For the past decade the volume of natural gas demanded at the going rate in many consuming areas has far exceeded the available supplies. Until supplies could satisfy demand, some type of rationing was necessary, either by a regulatory agency or by the companies themselves. ${ }^{11}$ This has been particularly

6. See Lewis, Public Utilities in 2 Governarent and Econoasic Lrfe 618 (Lyon et al., eds. 1940). More recently, protection of the investor has been recognizcd as a legitimate purpose of regulation, although this is perhaps more a protection alainst regulation. Cf. Bardes, op. cit. supra note 1,149 et seq.

7. The leading producing states in 1952, and the per cent of total U.S. net production from each were: Texas, 50.S1\%; Louisiana, 14.94\%; Oklahoma, 8.40\%; Califurnia, $5.94 \%$; Kansas, 5.20\%; New Miexico, 4.56\%; and Mississippi, 2.46\%. Computed from Bureau of Minfes, Mineral Market Report No. AIMS 229 (Nov. 9, 1953). Of the forty-one states which consumed natural gas in 1952, all but eight preduced less than their consumption, thus requiring interstate imports. See Table I, p. 849 infra, for data on the exporting states.

The marketed production of natural gas in the U.S. has increased consistently and, since 1946, dramatically. See Asr. GaS Ass'x, Gas FAcrs 46, table 27 (1953) ; SasitnWisrberLy 247, table 2. The proportion of total production moving in interstate commerce has increased from $19.5 \%$ in 1930 to $27.7 \%$ in 1940 to $47.4 \%$ in 1952 . SarrtiWIArBerly 46, table 27; BurEaU of Mínes, op. cit. supra. Interstate transmission lines have expanded concurrently. See Axr. GAS Ass's, Gas Ficts 62, table 39; FPC Press Release 7135, G-3306 (Feb. 27, 1954).

8. 52 Stat. $\$ 21$ (1938), as amended, 15 U.S.C. \$ 717 (1952).

9. Compare Natural Gas Act, stupra note 8, with Federal Power Act, 49 Stır. 838 (1935), as amended, 16 U.S.C. $\$ 791$ a (1952).

10. Natural Gas Act, § 7c, 52 Stat. $\$ 25$ (1938), as amended, 15 U.S.C. $\S 717 i(h)$ (1952).

11. For an example of state restriction see, Re Gas Supply and Requirements of Public Utilities Selling Natural Gas, 1 P.U.R.3d 15 (1953). 
true in states consuming more gas than they produce, ${ }^{12}$ and rec|uiring the services of interstate transmission lines which are subject to FPC regulation. Even while the excess demand for natural gas was being redtced by new or expanded transmission lines, ${ }^{13}$ an argument was advanced for permanent restriction on the rate and types of use of natural gas, in the interests of conservation. The FPC was the obvious institution to implement a policy of restricted consumption of the limited supply of gas.

Two proposals for a national natural gas allocation policy have been submitted to Congress. ${ }^{14}$ The first, ${ }^{15}$ introduced by Representative James I. Doliver in 1949 but never reported out of committee, ${ }^{10}$ declared that the public interest requires the establishment of a natural gas policy which would inter alia:

"conserve the reserves of natural gas for utilization which affords the highest social benefits to the public, consistent with reasonable rates and adequate service....

"assure to the fullest extent possible proper distribution of the remaining reserves of natural gas by giving first consideration to the use thereof by persons located in municipalities already served by such gas . . . .

"avoid undue preference or advantage between persons, localities, or classes of customers ...."17

Congressman Doliver admitted that his primary interest was to secure recognition of the prior claim of existing customers to the possibly limited supply of natural gas. ${ }^{18}$ The Federal Power Commission opposed this bill, primarily because of its vagueness, but it also pointed to an inconsistency between the clause granting priority to existing customers and that forbidding discrimination. ${ }^{19}$

The second bill, ${ }^{20}$ twice proposed unsuccessfully by Representative Frank E. Smith of Mississippi, was designed to prohibit the Commission "from authorizing extensions of natural gas service to points at a substantial dis-

12. All but eight states consume more natural gas than they produce. See TAvt.E I, p. 849 infra.

13. For market anticipations and expansion plans of the natural gas transmission industry, see Am. Gas Ass'N, Gas Requirements \& Supplies of Gas Utility \& PireLINE INDUSTRY (1954). Cf. Smith, The Gas Industry is a Unitcd Indistry, 52 Pub. Util. ForT. 669-73 (1953). For the past record of expansion, see any issue of AM. GAs Ass's, GaS FACTS; FPC Press Release 7135, G-3306 (Feb. 27, 1954).

14. Constitutional limitations prevent producing states from controlling the use of their natural gas in other states. Michigan-Wisconsin Pipe Line Co. v. Calvert, 347 U.S. 157 (1954); Pennsylvania v. West Virginia, 262 U.S. 553 (1923); Oklahoma v. Kansas Natural Gas Co., 221 U.S. 229 (1911).

15. H.R. 982, 81st Cong., 1st Sess. (1949).

16. Hearings before Subcommittee of House Committce on Interstatc and Forcign Conmerce on H.R. 79, H.R. 1758, H.R. 982, 81st Cong., 1st Sess. (1949).

17. Hearings on H.R. 79, silpra note 16 , at 3 .

18. Id. at 8,9 .

19. Id. at $164-66$.

20. H.R. 4884, 82d Cong., 1st Sess. (1951) ; H.R. 6189, 82d Cong., 2d Sess. (1952). 
tance from the sources of supply unless it finds that the new service will not impair present and future service to existing customers." 21 Congressman Smith stated the principle of his bill to be "merely the extension of a fundamental American policy that public utilities must fully serve the needs for which they are approved," and added that his proposal "would in no way impair the sound development of new markets for natural gas." FPC opposed. ${ }^{23}$

The Commission itself has repeatedly recommended that the Natural Gas Act be amended to give express authorization to the Commission "to allocate gas among customers of a natural gas company in periods of shortage." Congress has thus far ignored this request.

In acting on applications for certificates of public convenience and necessity by pipeline companies wishing to expand facilities for the interstate transmission of natural gas, the FPC has required evidence that the proposed project is economically feasible-that markets exist in which consumers are willing to provide sufficient revenues to cover the anticipated costs of the proposed service. ${ }^{25}$ Typically, however, the applicant and the Commission are faced by an embarras de richesses, with more potential customers than the lines can supply. ${ }^{26}$ An allocation problem thus arises.

Quite conceivably, since it has no specific statutory authority over gas uses, ${ }^{27}$ the FPC could have avoided all responsibility by requiring only that enough potential customers exist, and could have left the task of allocation to the applicant. ${ }^{28}$ Instead, the Commission issues allocation orders indirectly through its powers under several provisions of the Natural Gas Act:

1. The Commission is authorized to grant certificates "if it is found ... that the proposed service . . . is or will be required by the present or future public convenience and necessity." 29 The Commission has construed this

21. 31. FPC ANn. REP. 125 (1951).

22. 30 FPC Daily News Digest No. 15, p. 2 (1951).

23. 32 FPC ANv. REP. 134 (1952).

24. 31 FPC ANN. Rep. 145 (1951) ; 32 FPC ANn. Rer. 152 (1952); 33 FPC A:z: REP. 154 (1953). The FPC now carries on such allocation on the basis of Section 5(a) of the Natural Gas Act, which prohibits undue discrimination between custumers.

25. Re Kansas Pipe Line \& Gas Co., 2 F.P.C. 29, 45 (1939); 28 FPC As:a. REP. 57 (1948); Re Commonwealth Natural Gas Corp., 9 F.P.C. 70, 85 (1950).

26. See cases cited notes 83-88 infra. The allocation pattern may be established when the certificate is authorized. But the Commission may postpone this determinatiun until subsequent supplementary hearings if the existence of a market is satisfactorily established in the original hearings. Cf. Re Permian Basin Pipeline Co., FPC Opinion No. 249 (1953).

.27. But see Michigan Consol. Gas Co. v. FPC, 203 F.2d 895, 900 (3d Cir. 19531 (dictum): "The problem of the allocation of service to various customers is one whish calls for judgment within the Commission's peculiar and expert competence."

28. The Commission would still be required to review the applicant's allueatiun plans, to forestall undue discrimination, prohibited by Section 5(a) of the Natural Gas Act, 52 Stat. $\$ 23$ (1938), 15 U.S.C. \& 717d (1952).

29. Natural Gas Act, § 7(e), 56 Stat. \&4 (1942), 15 U.S.C. $\S 717 f(e)$ (1952). 
qualification as encouraging certain allocation policies and discouraging others. It may deny outright or in part an application to construct facilities designed to serve uses which it finds inconsistent with the public convenience and necessity.

2. Potential customers may petition the Commission to compel the applicant to serve them. The FPC is authorized to order service to such petitioners unless it would adversely affect the transmission company's ability to serve existing customers. ${ }^{30}$

3. The Natural Gas Act permits the FPC to "attach to the issuance of the certificate and to the exercise of the rights granted thereunder such reasonable terms and conditions as the public convenience and necessity may require."11 The Commission has interpreted this clause as an authorization to allocate supplies.

4. The Natural Gas Act also provides that no natural gas company shall "make or grant any undue preference or advantage to any persons or stibject any person to any undue prejudice or disadvantage, or . . . maintain any unreasonable difference in rates, charges, service, facilities, or in any other respect, either as between localities or as between classes of service."32 The FPC is empowered to eliminate discrimination. FPC emergency allocation orders are based on this provision. ${ }^{33}$

Theoretically, allocation of natural gas could be controlled completely and effectively through rate regulation, by reducing charges to "preferred" customers to encourage consumption by them, while raising rates for "undesirable" uses to discourage or even eliminate them. But for two reasons FPC rate policy has been ineffective in controlling allocation. First, the Commission's authority to fix rates is incomplete: it has no power to raise rates, but only to lower them to prevent discrimination. ${ }^{34}$ Furthermore, its authority

30. Natural Gas Act, $\S 7$ (a), 52 STAT. 824 (1938), 15 U.S.C. $\$ 717 f(a)$ (1952).

31. Natural Gas Act, $\S 7$ (e), supra note 29. Cf. FPC v. Idaho Power Co., 344 U.S. 17 (1952).

The FPC has consistently held that its allocation authority in certification cases takes precedence over any private sales contracts the applicant may have concluded, and has on occasion rejected the provisions of such contracts as discriminatory. Re Panhandle Eastern Pipe Line Co., FPC Opinion No. 229 (1952); Re Tennessee Gas \& Transmission Co., 6 F.P.C. 122, 131 (1947); Re Texas Eastern Transmission Corp., 6 F.P.C. 148,166 (1947).

32. Sections 4(b), 5(a), 52 Stat. 822,823 (1938), as amended, 15 U.S.C. $\$ \$ 717 \mathrm{c}$ (b), $717 \mathrm{~d}$ (a) (1952). Note that neither section is part of the certification clause, $\S 7$.

33. Emergency orders are issued when the immediate demands of the existing market of a transmission company temporarily exceed the capacity of the linc, e.g., during unusually cold weather. For an example of the complexities of an emergency allocation case and the Commission's approach, see the various cases, all under the title $R c$ Panhandle Eastern Pipe Line Co., 6 F.P.C. 137, 6 F.P.C. 196 (1947), 7 F.P.C. 48 (1948). See also 32 FPC ANN. REp. 111 (1952).

Note that the FPC is without authority to order expansion of facilities to climinate discrimination. Michigan Consol. Gas Co. v. FPC, 203 F.2d 895 (3d Cir. 1953).

34. Natural Gas Act, § 5(a), 52 Stat. 823 (1938), 15 U.S.C. § 717d(a) (1952). The Commission has recommended the amendment of this section to grant it express 
extends only to sales for resale, wholesale sales, and does not include direct sales to industrial customers, ${ }^{35}$ who often use natural gas as boiler fuel, a use condemned strongly by most proponents of restrictions on use. ${ }^{30}$ Thus, the FPC can exercise only an indirect influence over the rates on direct industrial sales: by allocating varying shares of the joint costs of the transmission company to the wholesale sales within its jurisdiction, it in effect allocates residual costs to the non-jurisdictional sales. ${ }^{37}$ Secondly, rate control has not been effectively employed as an allocative device even in regulating jurisdictional sales: rather than manipulate rates to infuence consumption patterns, the Commission requires all rates to be based on the historical costs of supplying the service. ${ }^{38}$ In addition, the Commission's criterion of the propriety of the rate level has been the adequacy of total revenues to cover total historical costs of providing the service, plus a fair return to the investors. ${ }^{39}$ This criterion, based on standards of fairness between consumers and producers, may be inconsistent with the objectives of conservation, which may call for rates in excess of costs, to discourage use of the resource. In

authorization to increase rates when necessary to correct undue discrimination. 31 FPC ANN. Rep. 145 (1951) ; 32 FPC ANN. Rep. 152 (1952) ; 33 FPC ANn. Rep. 154 (1953).

35. Natural Gas Act, § 1(b), 52 StAT. 821 (1938), 15 U.S.C. $\$ 717$ (b) (1952). The FPC, with one Commissioner dissenting, has recommended that this section be amended to "vest jurisdiction in the Commission over direct sales in interstate commerce of natural gas for industrial use," and that section 4(e) be amended to give it full authority to suspend rate schedules covering sales of natural gas for resale for industrial use only. 32 FPC ANN. REP. 152 (1952); 33 FPC ANn. REP. 154 (1953). Under § 1(b) the Commission does, however, have authority over the construction of facilities to serve industrial consumers.

36. See Note, 28 Ind. L.J. 587 (1953); Blachly \& Oatasan, Natural Gas asd THE PUBLIC INTERest C. IX (1947).

37. Cf. Biachly \& OAtaran, op. cit. stpra note 36, at 106-07: "The natural gas industry believes that direct and industrial sales have been required by the Federal Power Commission to bear too large a percentage of costs of operation, thereby resulting in too low an allocation of costs to the domestic load. Since it is the domestic use which requires peak load facilities, this cost should be charged to it and not allocated in such large part to industrial sales."

On FPC cost allocation policy see Alabama-Tennessee Gas Co. v. FPC, 203 F.2d 494 (3d Cir. 1953) ; Re Atlantic Seaboard Corp., FPC Opinion No. 225 (1452) ; Re Alabama-Tennessee Natural Gas Co., FPC Opinion No. 226 (1952); Re Northern Natural Gas Co., FPC Opinion No. 228 (1952); Re Colorado Interstate Gas Co., FPC Opinion No. 235 (1952) ; Re Alabama-Tennessee Natural Gas Co., FPC Opinion No. 25t (1953). On the economic principles of cost allocation, see BarNes, Ecososics of Pumuc Utrutry Regulation 327-31 (1942); Troxel, Econourics of Public Utilities $575-78$ (1947); Lewis, Overhead Costs 13-15, 44-55 (1949); Little, The Price of Freel (1953).

One writer believes the FPC should employ cost allocation deliberately to influence the use of natural gas. See Pegrum, The Natural Gas Industry: An Economic Appraisal of Public Policy, 29 J. LAND \& P.U. ECoN. 168 (1953).

38. The FPC has followed this method consistently since Cleveland v. Hupe Natural Gas Co., 3 F.P.C. 150 (1942), and FPC v. Hope Natural Gas Co., 320 U.S. 391 (1944), in which the principle was established and approved by the Supreme Court.

39. Ibid. 
short, the FPC has chosen to set rates which result in its concept of fair income distribution, rather than optimum utilization of the resource, thus leaving the latter problem to be solved, if at all, through dircat allocation by the transmission companies or the Commission.

\section{Federal Power Commission Allocation Policy}

The significant aspects of FPC policy have been formulated in the debates on allocation of natural gas between (a) domestic and foreign consumers, (b) producing and non-producing states, (c) "superior" and "inferior" uses, and (d) existing and new customers.

\section{Domestic v. Foreign Consumers}

FPC control over the international movement of natural gas is exercised through the certification clause ${ }^{40}$ and a separate provision of the Natural Gas Act directing the Commission to issue certificates unless "it finds that the proposed exportation or importation will not be consistent with the public interest." 41 The latter clause provides further that the Commission may grant applications "in whole or in part, with such modifications and upon such terms and conditions as the Commission may find necessary or appropriate, and may ... make such supplemental orders in the premises as it may find necessary or appropriate." 42 The Commission has additional indirect allthority over these movements through the delegation to it of the authority to issue the Presidential Permits required for all importation and exportation of natural gas. ${ }^{43}$

Few applications for permission to import or export natural gas have been filed, and up to the present only small volumes of gas have moved across United States borders. ${ }^{44}$ Until recently, the Commission consistently recognized the prior interests of domestic consumers: it approved export only when the needs of the applicant's domestic customers would not be impaired, and then made foreign service subject to complete interruption at any time

40. Natural Gas Act, $\S 7$ (c), 52 Stat. 825 (1938), as amended, 15 U.S.C. $\$ 717 \mathrm{f}(\mathrm{h})$ (1952).

41. Natural Gas Act, § 3, 52 Stat. 822 (1938), 15 U.S.C. § 717b (1952).

42. Ibid.

43. "President Eisenhower on September 3 issued an Executive Order [Exec. Order No. 10485, 18 FED. REg. 5397 (1953)] delegating authority for the issuance of such permits to the Federal Power Commission, with the permit to be signed by the Chairman of the F.P.C.

"The Commission regards the issuance of the export permit as purely a ministerial act ...." FPC Press Release 6855, G-3124 (1953).

44. In 1952, exports to Canada were 5,900 million cubic feet; to Mexico, 21,556 million cubic feet; imports from Canada were 7,803 million cubic feet; from Mexico, 4 million cubic feet. Compare these data with the total U.S. marketed production in that year of $8,003,309$ million cubic feet. Bureau of Mines, Mineral Market Re'pott No. MMS 2229 (Nov. 9, 1953). 
the needs of the American markets required. 15 But the discovery of major reserves of natural gas in western Canada has revised FPC export policy. While proved Canadian reserves are still small compared with United States reserves, ${ }^{46}$ their growth potential is great. ${ }^{17}$ Faced with the possibility of reciprocity, the Commission recently authorized the export of up to 22.6 million cubic feet of gas per year to eastern Canada, over the objection of one Commissioner, and without the usual proviso making that service subordinate to American needs. ${ }^{48}$ Confronted with competing applications to serve the Pacific Northwest, the Commission recently chose the applicant with its gas supply in the United States, in preference to one which planned to use Canadian gas exclusively.99 Since the decision, however, the two companies have planned a joint project which would draw on both United States and Canadian reserves.50

Canada has generally been as reluctant as the United States in permitting the exportation of gas. Natural resources in Canada are typically owned by the provinces, which share with the Dominion government the authority to allow export. 51 At the present time the only Canadian exports serve the Anaconda Copper Mining Co. in Montana, a service which was authorized by special act of the Alberta legislature at the request of American defense production officials. 52 Like many producing states in this country, Canada apparently cannot decide whether its best interests lie in retaining reserves

45. See $R e$ Reynosa Pipe Line Co., 5 F.P.C. 130, 142 (1946) (limited export permitted under the provision that authorization should not constitute ground or justifieation for applicant to refuse service to any customers in the United States); Panhandle Eastern Pipe Line Co., 5 F.P.C. 472, 475 (1946) (delivery of gas to Canadian customers "shall be curtailed or interrupted whenever ... required for the protection of deliveries of natural gas .... to any and all of applicant's customers in the United States"); Re Reynosa Pipe Line Co., 4 F.P.C. 282 (1945).

46. Alberta and British Columbia reserves have been estimated at cight trillion cubic feet. 32 FPC Daily News Digest No. 92, p. 4 (1952). While data on total Canadian reserves are not available, the predominant position of these two Canadian provinces is indicated by the fact that in 1952 they accounted for over $82 \%$ of total Canadian production. Id. at 266.

47. William C. Mainwaring, Vice-President of the British Columbia Electric Railway Co., Ltd., which serves Vancouver, B.C., with manufactured gas at present, has prophesied that "within five to 10 years Canada will have developed mure natural gas than it will know what to do with," and will compete with United States producers from California to the Great Lakes. Wall Street Journal, Miay 15, 1952, p. 3, cul. 4.

48. Re Tenn. Gas Transmission Co., FPC Opinion No. 261 (1953).

49. N.Y. Times, June 19, 1954, p. 20, col. 3: The Commission was unwilling "to authorize a most important new project to serve a major area . . . which from the outset will be completely tied to and wholly dependent upon an exclusive source of supply entirely beyond the control of agencies of the U.S."

50. The Economist, Dec. 25, 1954, p. 1083; The Sunday Times (London), Dec 19, 1954, p. 2, col. 2.

51. Letter to the author from G.S. Hume, Director-General of Scientific Services, Department of Mines and Technical Surveys, Canada, dated April 6, 1951.

52. N.Y. Times, Feb. \&, 1952, p. 33, col. 5. Canada also granted an export and transmission permit to Westcoast Transmission $C_{0}$, whose project to serve the north- 
to further its own industrial development, or in profiting from sales in outside markets. And the availability of American markets has been impaired by the refusal of the FPC to permit importation without the guarantees of continued service required in all certification cases. ${ }^{53}$

The propriety of importing and exporting natural gas depends on many factors, including basic questions of foreign policy and resource development. It seems regrettable, under these circumstances, that the President has delegated blanket authority over Presidential Permits to the FPC. As a minimum, a statement of executive policy is needed to guide the deliberations of the Commission. In the absence of such guidance, the Commission's cautious policy appears to have been satisfactory for the disposition of small volumes of gas. It may reveal its weaknesses, however, when and if large scale international movements of the resource become necessary.

\section{Regionalism}

Although at issue in few formal certificate cases, geographical allocation of natural gas has aroused considerable discussion. Commissioners Leland Olds and Claude Draper and representatives of the coal and railroad industries ${ }^{\text {th }}$ have been the chief sponsors of a proposal that the Commission recognize the superior right of producing states to the resource, and discourage transmission of gas to more heavily industrialized areas of the nation, particularly when it is to be used for boiler fuel as a substitute for coal readily available there. Impressed by the apparent waste of shipping gas from an area poor in other fuels to areas rich in them, and hopeful of the balance which industry, attracted by cheap natural gas, could add to the one-sided economies of the southern gas producing states, Olds and Draper have urged curtailment in interstate shipments. The states themselves would find curtailment constitutionally impossible, ${ }^{55}$ but the FPC could implement such a policy simply by denying applications for the construction of transmission lines as contrary to the "public convenience and necessity." The proposal is difficult to evaluate, as even the producing states have discovered. They are faced with a choice between securing present revenues from the widest possible market for their mineral and relying on the indefinite and only potential returns from their own industrial development. 56

The facts are instructive and relatively conclusive. In 1952, the last year for which complete data are available, while twenty-nine states produced

western states was denied in favor of the proposal of Pacific Northwestern Pipeline Co. Cf. note 49 supra.

53. See, e.g., Trans-Continental Gas Pipe Line Co., 7 F.P.C. 537 (1948); Atlantic Seaboard Corp., 7 F.P.C. 926 (1948) ; Re Texas Gas Transmission Corp., 8 F.P.C. 190 (1949) ; Re United Gas Pipe Line Co., 10 F.P.C. 35 (1951).

54. Olds-Draper $§$ IV, VI; Blachly \& Ontman, Natural Gas and tule Punlic INTEREST C. IX (1947).

55. See note 14 supra.

56. See, e.g., testimony quoted in Olds-Draper $\S$ III, passim, and statement of the director of the oil conservation commission of New Mexico, who would encourage new 
some natural gas, only eight exported more than they imported.57 Data on these eight are presented in Table I, from which several points should be noted:

1. Without restrictions on exports, between 1939 and 1952 each of the eight states narrowed the spread between its per capita income payments and the national average, with the single exception of IVyoming, which stands above the national average.

2. Over eighty per cent of the natural gas in interstate transport comes from two states, Texas and Louisiana, both of which consume locally more than they export.

3. While Louisiana stands fortieth in the rank of states by per capita income payments-and we may take per capita income as a rough measure of relative economic prosperity-Texas ranks twenty-eighth, or close to the national average.

TABLE I

Natural Gas Exporting States-1952

\begin{tabular}{|c|c|c|c|c|c|}
\hline State & $\begin{array}{c}\text { Natural Gas } \\
\text { Exported Ont } \\
\text { Balance } \\
\text { (million cubic } \\
\text { feet) } 58\end{array}$ & $\begin{array}{l}\text { Percent of } \\
\text { Exports }\end{array}$ & $\begin{array}{c}\text { Percent of Local } \\
\text { Production } \\
\text { Exported } 5 s\end{array}$ & $\begin{array}{l}\text { l Rank, in Per } \\
\text { Capila Income } \\
\text { Payments } 50\end{array}$ & $\begin{array}{c}\text { Pereml Inercase } \\
\text { Per Capita } \\
\text { Income Pay- } \\
\text { ments, } \\
1939-195250\end{array}$ \\
\hline Kansas & 123,892 & 3.96 & 26.87 & 15 & 343 \\
\hline Louisiana & 621,913 & 19.88 & 46.99 & 40 & 241 \\
\hline Mississippi & 57,950 & 1.85 & 26.57 & 48 & 307 \\
\hline Neẃ Mexico & 152,781 & 4.88 & 37.85 & 33 & 290 \\
\hline Oklahoma & 204,733 & 6.54 & 27.52 & 36 & 278 \\
\hline Texas & $1,931,307$ & 61.73 & 42.90 & 28 & 262 \\
\hline West Virginia & 3,691 & .12 & 2.02 & 38 & 26 \\
\hline Wyoming & 32,153 & 1.03 & 35.22 & 21 & 183 \\
\hline U.S. Average & & & & & 204 \\
\hline
\end{tabular}

A case for restriction on natural gas exports, then, could be made only for Louisiana and, perhaps, Mississippi. ${ }^{60}$ Any FPC policy would have to be

pipelines to pipe natural gas out of the state before it "becomes an obsolete fuel .... I'd be tickled to death if someone can come and get it. It would mean alditional development for northwestern New Mexico and additional revenue for the state." 34 FPC Daily News Digest No. III, p. 2 (1953). The Chairman of the Tevas Railroad Commission testified before the Natural Gas Investigation that "53 cents out of the State's general tax dollar came from oil and gas and their directly related industries." Olds-DRAPER 47. For the contrary position, see contentions of the appealing states in cases cited note 63 infra.

57. Bureau of Mines, Mineral Mlarket Repost No. Misis 2229 (Nov. 9, 1953).

58. Calculated from data in Bureau of Mines, op. cit. supra nute 57.

59. Calculated from data in Tre Ecovonrrc Alar.anac, 1953-1954, at 502-03 (1953).

60. Louisiana because it exports so large a percentage of its production and has relatively low per capita income payments; Mrississippi because it stands so luw in income payments. On New Mexico cf. note 56 supra. 
highly discriminating and could not rely on blanket prohibitions of exports from producing states or it would work to the detriment of other economically low-ranking states which on balance are importers of natural gas, ${ }^{01}$ as well as those exporting states which neither want nor need FPC protection. And there is a danger that restrictions on interstate movement of natural gas might be followed by restrictions on interstate exploitation of other resources. ${ }^{62}$ The FPC has been understandably reluctant to embark upon a program of geographical allocation. In several cases the point was argued, but in each the Commission decided to permit the exportation requested. of It has thus rejected general claims to priority by producing states, but has indicated that it would be receptive to evidence of specific injury. ${ }^{04}$ No such persuasive evidence has yet been offered the Commission. ${ }^{65}$

61. Seven of the ten states standing lowest in per capita income payments are inporters on balance of natural gas: Georgia, Tennessee, North Carolina, Kentucky, Aliıbama, South Carolina, and Arkansas.

62. See Znmmernann, World Resources and Industries 564 (1951): "The argument that Texas gas should be reserved for a Texas chemical industry yet to be built ... is a return to mercantilism and to a particularly primitive mercantilism at that. Any attempt on the part of one state or a group of states to reserve for local or regional use a national asset which inevitably is also a state and a regional asset is bound to bring down upon it a storm of protest and lead to retaliation which will play havoc with the very roots of this nation's strength." See also Note, 28 INv. L.J. 587, 609-11 (1953); Pegrum, The Natural Gas Industry: An Economic Appraisal of Public Policy, $29 \mathrm{~J}$. LAND \& P.U. ECoN. 168, 181 (1953).

63. In $R e$ Memphis Natural Gas Co., 4 F.P.C. 197 (1944), the application was opposed by the Louisiana Public Service Commission and the Louisiana Department of Conservation, who argued that since Louisiana had no coal or water power resaurces, and since its gas would last only seventeen years at present consumption rates, it should not be exported to other states where other fuels were available. Id. at 207-08. T'he National Coal Association, the United Mine Workers, and various railroad workers' unions joined in the protest. The application for export was supported by the Railrond Commission of Texas (the leading gas-producing state), the Independent Natural Gas Association of America, and numerous land and royalty owners in Louisiana. Id. at 207. 09. The FPC approved the application on the following grounds: (1) Producing states themselves were not agreed on the undesirability of export; (2) Prohibition of this interstate movement would have discriminated against Tennessee, because gas was already being transmitted from Louisiana to other states without restriction; (3) The volume of gas involved was only01.3\% of total Louisiana production; (4) The problem was to be studied thoroughly in the pending Natural Gas Investigation. The appeal of Louisiana was denied. Dep't of Conservation of Louisiana v. FPC, 148 F.2d 746 (5th Cir.), cert. denied, 326 U.S. 717 (1945). See also Re Reynosa Pipe Line Co., 5 F.P.C. 130 (1946); Re Panhandle Eastern Pipe Line Co., 4 F.P.C. 263 (1945).

64. In San Juan Pipe Line Co., 8 F.P.C. 991, 995 (1.949), the FPC approved the movement of gas from Colorado to California and Arizona, and rejected the contention of Colorado that Colorado consumers should be given priority, but adlded that "there was no showing that the benefits to the people in the state of Colorado would be greater than to the people of the states of California and Arizona, or that injury would occur if the gas was transported as proposed by these applications."

65. The Commission has thus held consistently, although not dogmatically, to a view it predicted as early as 1940: "Careful study of the entire problem may lead to the con* 


\section{Superior v. Inferior Uses}

The FPC has been more receptive to another argument, advanced by the coal industry in particular, that it should consider the use to which the natural gas shipped in interstate commerce would be put and give priority to so-called "superior" uses, while forbidding or curtailing the use of gas for "inferior" purposes. ${ }^{66}$ The net result would be a decrease in the total consumption of gas. This argument has two aspects. First, it presupposes that the rate of utilization of natural gas is excessive, from the social point of view, because private markets, for some reason, overvalue present consumption relative to future consumption, to the extent of using gas today which would serve a superior future purpose. Second, the proponents argue that injury to the coal industry from rapid extension in the use of natural gas outweighs the benefits to the rest of the economy.

Because its certification authority prior to 1942 extended only to applications for facilities in areas already being served by other natural gas companies, ${ }^{67}$ the FPC concluded that Congress had not intended it "generally" to weigh the broad social and economic effects of the use of various fuels," position supported by the courts. ${ }^{\circ 9}$ But in 1942 an amendment to the Natural Gas Act gave the FPC authority over all extensions of interstate pipelines, ${ }^{\text {T0 }}$ and the Commission began to give consideration to the argument of the coal industry. In instituting a comprehensive Natural Gas Investigation in 19+4, it included an inquiry into the problem of end-use control as a major objective. ${ }^{71}$

clusion that use of natural gas should be restricted by functions rather than by areas." 20 FPC ANN. REP. 79 (1940).

66. The National Coal Association urged the FPC to refuse to issue certificates where gas "will be used as boiler fuel or will be used for inferior purposes for which adequate supplies of bituminous coal are available," and requested Congress to adupt a "national fuel policy" to the same effect. 34 FPC Daily News Digest No. 99, p. 4 (1953). See also Blachly \& Oataran, Natural Gas and tme Punlic I:iterest 12035 (1947); Note, 28 IND. L.J. 587, 606-09 (1953); Sarrth-W TrBerly $269-73$ and, for data on the uses of natural gas, pt. VIII, passim; Pegrum, op. cit. supra note 62.

67. Natural Gas Act, \& 7(c), 52 StAT. 825 (1938).

68. Re Kansas Pipe Iine \& Gas Co., 2 F.P.C. 29, 57 (1939).

69. Alston Coal Co. v. FPC, 51 P.U.R. (N.S.) 245 (1943).

70. 56 Stat. $\$ 3$ (1942), 15 U.S.C. $\$ 717 f(c)$ (1952).

71. See Natural Gas Investigation, 4 F.P.C. 725, 727 (1944). In the same sear, the Commission received support from Supreme Court opinions in FPC v. Hope Natural Gas Co., 320 U.S. 591 (1944). A dictum in the majority opinion in this rate case noted that "when it comes to cases . . . of extensions of facilities or service, we may assume ... considerations of conservation are material to the issuance of certificates of publit convenience and necessity." Id. at 612. But the Court sustained a rate order which, in the opinion of Justice Jackson, dissenting, violated principles of conservation: "Utilization of natural gas of highest social as well as economic return is dumestic use fur cooking and water heating, followed closely by use for space heating .... The Commission has power to fix a price that will be both maximum and minimum and it has the incidental right, and I think the duty, to choose the economic consequences it will promote or retard in production and also more importantly in consumption ...." /d. at $634-35,655-56$. 
The reports of all four Commissioners at the conclusion of the investigation gave cautious approval to a policy of weighing end-use in certificate cases. Commissioners Nelson Lee Smith and Harrington Wimberly suggested, as the test of a superior use, the willingness of the consumer to pay a full share of the annual costs of production. This would exclude low price customers who buy low cost off-peak service. Smith and Wimberly approved those uses of gas "which especially require assured service of a premium quality fuel and which can therefore pay a premium price for it."72 No restrictions on use other than willingness to pay full cost were, in their opinion, desirable. ${ }^{73}$ Commissioners Olds and Draper approached the problem of end-use control indirectly, for their primary interest was to assure consumption priority of producing states over states with reserves of coal. By implication they approved any use of natural gas in the producing states, but advocated a "survey of the nature of industrial loads as a basis for determining for each kind of use in each area whether it reasonably requires natural gas from the Southwest." 74

The Natural Gas Investigation caused no apparent variation in the policy of the Commission toward end-use control in certification cases. By piecing

72. SMIrth-WIMrerLy 354. Marketing policies "can and should be accomplished in economic terms of price and service, rather than by imposition of some kind of arbitrary determinations as to 'proper' uses of natural gas in comparison with other fuels." $1 i$. at 29. Smith and Wimberly argued that interruptible sales of gas to industry at low prices are undesirable, attacking the transmission companies' emphasis on high load factors, i.e., use of the capacity of the transmission lines a large share of the time. The companies' view is that off-peak industrial sales raise load factors and decrease the average cost of transmission, thus permitting lower rates for non-industrial customers. Smith and Wimberly found that cost savings increase more slowly as load increases and argued that lower unit costs with very high load factors are offset by the social loss in the use of gas for inferior purposes. They distinguished between off-peak users, who buy gas only if the rate is less than the price of competing fuels, and firm industrial customers, who use gas throughout the year and are willing to pay their full share of the costs. They concluded that a shift from interruptible to firm industrial users would improve the low load factors caused by the seasonal fluctuations in domestic use to some extent, and that with "this up-grading and repricing of industrial markets for gas, high system load factors will be less important to the successful operations of pipe lines." $I d$. at 293. For a similar view see Pegrum, op. cit. supra note 62.

73. Commissioner Wimberly had elsewhere suggested that the states, rather than the FPC, should carry the main responsibility for natural gas conservation. Speech before the Interstate Oil Compact Commission, reported in 51 PuB. Utrl. Fort. 102 (1953). While this proposal may be proper for short run emergency allocation problems, it would seem that the FPC, with broader control over sources of supply, is better equipped to perform any permanent allocative function.

74. Olds-Draper 116. Commissioner Olds stated his position most clearly on another occasion: "My position . . . is that it is desirable that gas be not used for inferior purposes, for purposes where it simply is used because it is a cheaper fuel and not because it has certain characteristics which make it a desirable fuel for industrial processes, in areas outside the general areas where gas is one of the main indigenous energy reserves." Hlearings before Subcommittee of House Committee on Interstate and Foreign Commerce on H.R. 79, 81st Cong., 1st Sess. 263 (1949). 
together the fragments found in FPC decisions, that policy can be summarized as follows:

1. The Commission is generous in granting permission to representatives of competing fuels to intervene in certificate cases, not only to present their arguments against certain uses of fuel, but also to attack all phases of the applicants' evidence. ${ }^{75}$

2. The Commission will consider injury to the coal industry only if specific evidence of actual or probable injury is presented. ${ }^{70}$

3. The Commission is reluctant to permit use of natural gas for boilerfuel. ${ }^{77}$

4. For other uses, the Commission relies predominantly on the showing of a demand for natural gas service in preference to coal. ${ }^{78}$

The FPC has consistently granted priority to one "superior" use of natural gas-national defense. In fact, because the Commission received comprehen-

75. Re New York State Natural Gas Corp., 9 F.P.C. 315 (1950); Re Commonwealth Natural Gas Corp., 9 F.P.C. 70 (1950); Re Trans-Continental Gas Pipe Line Co., 7 F.P.C. 24, 27, 42-44 (1948) ; Michigan-Wisconsin Pipe Line Co., 6 F.P.C. 1 (1947). In one case the Presiding Examiner was irritated by intervenor's counsel "acting as public counsel in generally probing facts not pertinent to any special interest of the intervenors ...." Report of Presiding Examiner, pp. 21-22, $R e$ Texas Eastern Transmission Corp. (Feb. 17, 1949) (mimeo.).

The right of coal representatives to appeal certificate decisions has been established. In East Tenn. Natural Gas Co., S F.P.C. 836 (1949), the Commission approved construction of facilities to supply gas to the Oak Ridge atomic energy installation fur supplemental boiler fuel use on the basis of representations by the AEC that service was necessary for defense. On appeal by the National Ctal Association the FPC contended that injury to the coal interests was "too remote and conjectural to qualify them as parties aggrieved, the basis upon which a petition to review an order of the Commission must be grounded." 31 FPC Axx. REp. 124 (1951). The Commission won the case but lost this procedural issue; the court affirmed the certificate order but upheld the right of the coal interests to appeal. National Coal Ass'n v. FPC, 191 F.2d 462 (D.C. Cir. 1951).

76. Re New York State Natural Gas Corp., 9 F.P.C. 315 (1950) (evidence that New York consumed $31 \%$ of national anthracite production insufficient in absence of evidence extension of gas service would actually displace anthracite); $R c$ Commonwealth Natural Gas Corp., 9 F.P.C. 70 (1950) (evidence of $8,000,000$ ton displacement of "residue" cosl which would block mines and cause $\$ 226,000,000$ loss in production of all coal influential, though not "determinative" in defeating application for boiler fuel service); Re Trans-Continental Gas Pipe Line Co., 7 F.P.C. 24, $43-44$ (1948); 31 FPC Axsi. REP. 124 (1951).

77. Re Texas Eastern Transmission Corp., F.P.C. Opinion No. 231 (1953); Rc Mississippi River Fuel Corp., F.P.C. Opinion No. 250 (1953); Re Commonwealth Natural Gas Corp., 9 F.P.C. 70 (1950); Northern Natural Gas Co., 4 F.P.C. 1099 (1945). But see Re Mississippi River Fuel Corp., F.P.C. Press Release Xo. 7025, G-3230 (Dec. 15, 1953) (authorizing limited sales for boiler fuel use under restricted conditions).

78. Re Mississippi River Fuel Corp., 5 F.P.C. 206 (1946); Ke Natural Gas Pipeline Co., 5 F.P.C. 85 (1946); $R e$ Wisconsin Southern Gas Co., 4 F.P.C. 339 (1945).

The Commission has often relied on the general statement that "the ecunumic impact upon the coal industry ... constitutes only one of the factors to be taken into accuunt 
sive authority over pipeline certification in 1942, the first three and a half years of broad FPC regulation were dominated by wartime considerations. At that time actions of the Commission in authorizing pipelines and allocating gas supplies required the concurrence of the War Production Board, which controlled the necessary steel supplies. ${ }^{70}$ During the war the Commission generally restricted certificates to facilities designed to serve defense industries and to maintain supplies to existing markets. ${ }^{80}$ The Korean war again created a steel shortage and the need for defense priorities. Allocation of steel for oil and gas pipelines was a function of the Petroleum $\Lambda$ dministration for Defense (PAD), under the Defense Production Administration. ${ }^{81}$ Besides allocating steel to pipeline companies, primarily for the completion of projects already begun, the PAD introduced restrictions on the inclustrial and space-heating use of natural gas by existing customers in an order which was terminated in March $1953 .^{82}$ Thus, the paramount claim of defense industries to natural gas supplies has been readily recognized by the Commission.

\section{New v. Existing Customers}

A final problem of allocation policy in certification cases is the relative priority of existing customers of natural gas companies who desire expanded service, and new customers. This issue arises when an existing pipeline company plans a major expansion and existing but not yet saturated markets compete with unserviced areas for increased supplies. The FPC's scale of priorities is based on the costs of supplying the competing areas and on their relative needs, in terms of alternative fuels available and existing uses of natural gas. The Commission is inclined to approve the extension of service to those areas in which one, or preferably several, of the following conditions exist:

1. Existing supplies of natural gas are so inadequate that emergency restrictions on use have been necessary ${ }^{83}$

in the Commission's determination" of public convenience and necessity. Michigan-Wisconsin Pipe Line Co., 6 F.P.C. 1, 27 (1947). See also Re Natural Gas Pipeline Co., 5 F.P.C. 85 (1946); Re Mississippi River Fuel Corp., 6 F.P.C. 280, 289 (1947).

79. The Commission and the WPB issued a joint statement defining their relationship. FPC, The First Five Years Under the Natural Gas Act, Report to tilt Comaittee on Interstate and Foreign Conmerce 23 (1944).

80. $R e$ Reynosa Pipe Line Co., 4 F.P.C. 282 (1945); Re Panhandle Eastern Pipcline Co., 4 F.P.C. 263 (1945); Re Memphis Natural Gas Co., 4 F.P.C. 197 (1944); Re Hope Natural Gas Co., 4 F.P.C. 59 (1944); Re Tennessee Gas and Transmission Co., 3 F.P.C. 442 (1943). See also the FPC-WPB joint statement cited note 79 supra.

81. See Rather, The Gas Industry and the PAD, 48 Pur. Utrl. Fort. 534 (1951).

82. 29 FPC Daily News Digest No. 20 (1951) ; 33 id. No. 31 (1953) ; N.X. Times, Aug. 16, 1951, p. 35, col. 5.

83. Re Texas Eastern Transmission Corp., 8 F.P.C. 139, 150, 151-53 (1949); Kic Tennessee Gas \& Transmission Co., 6 F.P.C. 122, 131, 132 (1947); Ri Texas Eastern Transmission Corp., 6 F.P.C. 148, 164, 165, 167-68 (1947). 
2. Existing sources of supply are depleted. ${ }^{84}$

3. The substitution of natural gas for manufactured gas will result in significant savings in cost, or obviate constructing additional, higher-cost, manufactured gas facilities. ${ }^{85}$

4. The proposed service area is close to the interstate transmission line, so that a connection can be made inexpensively. ${ }^{80}$

5. Firm commitments have been made for the distribution of the natural gas. 87

6. The gas will be used primarily for cooking and water heating, and not for industrial purposes or space heating. ${ }^{88}$

Saturation of demand in markets currently being served should not, in the Commission's opinion, precede the extension of service for high value uses to new markets. 89

Thus, in these four major areas of consumer competition, the Commission attempts to approximate the allocative results of price competition in a market where the price of gas could rise in response to demand. By indirect methods the FPC seeks to allocate available gas to those willing to pay the highest premium above the cost of supply, while keeping rates at a level which it believes will result in a fair return to the producer.

\section{Economic and Soctal Aliocation Criteria}

The natural gas allocation policies of the FPC can be evaluated within a dual framework of economic and social norms. FPC allocation may first be compared with the allocative results which would be achieved by a perfectly competitive, private economic market. And, since social considerations may suggest variations from private economic standards, the results of FPC policy can be related, at least conceptually, to a socially optimum allocation pattern. ${ }^{00}$

In nonregulated, freely competitive markets, the efficient allocation of resources and products is effected by the reactions of producers and consumers

84. Re Texas Eastern Transmission Corp., 6 F.P.C. 148, 162 (1947).

85. Re Texas Eastern Transmission Corp., 8 F.P.C. 139, 154-55, 157, $158-59$ (1949) : Re Natural Gas Pipeline Co. of America, 5 F.P.C. 85, 99-100, 101 (1946); Re Mississippi River Fuel Corp., 5 F.P.C. 206, 213-14 (1946).

86. Re Northern Natural Gas Co., F.P.C. Press Relense 7044, G-3245 (Dec. 28, 1953); $R e$ Transcontinental Gas Pipe Line Corp., 9 F.P.C. 32, 42-43 (1950); Rc Texas Eastern Transmission Corp., 8 F.P.C. 139, 151 (1949); Re Texas Eastern Transmission Corp., 6 F.P.C. 148, 167 (1947) ; Re Natural Gas Pipeline Co., 5 F.P.C. 85, 100 (1946).

87. $R e$ Northern Natural Gas Co., F.P.C. Press Release 7044, G-3245 (Des. 28, 1953); $R e$ Texas Eastern Transmission Corp., 8 F.P.C. 139, 151 (1949); Ke Texas Eastern Transmission Corp., 6 F.P.C. 148, 161, 163-64, 166 (1947); Re Tennessee Gas \& Transmission Co., 6 F.P.C. 122, 134-35 (1947).

88. Re Texas Eastern Transmission Corp., \& F.P.C. 139, 101 (1949); Ite Texas Eastern Transmission Corp., 6 F.P.C. 148, 162, 165-66 (1947); Ke Natural Gas Pipeline Co., 5 F.P.C. 85, 100 (1946).

89. Re Texas Eastern Transmission Corp., 6 F.P.C. 148, 167 (1947).

90. Cf. Ciriacy-Wantrup, Resource Conservation (1952). 
to prices. Consumers buy final products if the benefit or utility they expect to receive exceeds the price they must pay. Individuals expecting the highest benefit are willing to pay the highest price. ${ }^{91}$ Producers, on the other hand, sell to those customers for whom the spread between cost of supply and selling price is the greatest. If costs are the same for all customers, their willingness to pay will alone determine allocation of the product. But if costs differ, the producer may, profitably, sell to a customer offering a lower price than another customer provided the difference in the costs of supplying the two customers exceeds the difference in offer prices. It is important to note that for maximum profit and optimum economic allocation, the spread between consumer valuations and costs is the determining consideration. The former alone is an inconclusive factor. ${ }^{92}$

In the natural gas industry the operation of these market forces is impeded and the pattern of allocation distorted. Price is set by regulation at that level which provides what the FPC considers a fair return to the producers, not at the level where the supply available would be equated to the amount demanded. As a consequence, allocation may be based on chance, rather than on costs and valuations. Critics of the price, i.e., rate, policy of the FPC have pointed out the dangers of wasteful use of gas which may result. ${ }^{93}$ But waste is not inevitable. Even with the existing method of rate determination, the economically desirable pattern of allocation can be achieved through a policy of direct allocation by the FPC and other regulatory

91. A major qualification to the theory of correspondence between offer price and benefit to consumers is that the prices consumers offer to pay for products accurately represent the values of products to them only if the value of money is the same to all consumers. See Lerner, Economics of Control c. 3 (1947); Due, Inteknepiate: Economic Analysis 521-24 (1950); Pigou, Socialism Versus Capitalism c. 2 (1947); Lange \& Taylor, ON the Economic Theory of Socialism 98-103 (1938); Bown, Toward Social Econony c. 19 (1948). A common (but unprovable) assumption is that the value of one unit of money to individuals varies inversely with their income.

The variation in the value of money from individual to individual is ignored in the discussion above because it is felt that, however much variation there may be between individuals, these variations will tend to offset each other within groups of consumers. There is no obvious reason why the group of consumers demanding natural gas for domestic purposes should differ significantly in this respect from those demanding the products of commercial and industrial users of gas.

92. The manufacturer purchasing gas follows a similar maximization process. However, he attempts to maximize the difference between his costs and his revenues rather than between his costs and subjective valuation of the benefits of his product. In competitive markets his revenues mirror the subjective valuations of his product to the ultimate consumers.

93. The argument is the same which raged for 60 years over the "proper" valuation method for determining fair return: historical cost or reproduction cost. Sce Smyth v. Ames, 169 U.S. 466 (1898) ; McCardle v. Indianapolis Water Co., 272 U.S. 400 (1926) ; FPC v. Natural Gas Pipeline Co., 315 U.S. 575 (1942); FPC v. Hope Natural Gas Co., 320 U.S. 591 (1944). See also the discussion in Barnes, Economics of Pumte Utility Regulation cc. 11-14 (1942); Troxel, Economics of Public Utilities cc. 12-14 (1947). Proponents of the reproduction cost standard argue that unless rates are set equal to cur- 
agencies, such as the PAD and state utility and natural resource commissions.

FPC rate policy is by no means the only impediment to competitive equilibrium. Delays in expanding facilities and state restrictions on natural gas output also contribute to the excess of the amount demanded over the amount supplied. But whatever the cause of noncompetitive market conditions, direct regulation could at least theoretically emulate competitive allocation.

Under conditions of disequilibrium in natural gas markets, the proper allocation policy is clear: the gas should be sold-at whatever price ${ }^{03}$ - to those classes of customers willing to pay the most in excess of their cost of supply. The FPC has followed this criterion fairly consistently, if not too articulately at times. Where demand is high and costs of supplying a new area fairly low, the FPC approves extension of service. It grants priority to sales for cooking and water heating over sales for space heating. The former uses are preferable on two grounds: the cost is lower because of higher load factors, ${ }^{95}$ and consumers would presumably be willing to pay more for gas for these purposes. ${ }^{96}$ In considering requests for expansion of service to new areas, the Commission has correctly considered the relative costs of supply, as well as the intensity of demand. However, it has not given the same consideration to costs of supply in dealing with proposals to use natural gas for boiler fuel. These typically off-peak sales have a lower cost of supply because they require no additions to the capacity of transmission lines, using existing capacity when it is not desired by other customers. ${ }^{07}$ Apparently the FPC disapproves this type of use only because these customers would be willing to change back from natural gas to other fuels at lower prices than would the domestic customer. Yet, as we have argued above, the relevant criterion is not offer price alone but the divergence between prices and costs of supply. The FPC overemphasizes consumer valuation and underemphasizes cost. Its error can lead only to an unbalanced allocation policy and uneconomical consumption.

rent costs (including the cost of replacing the existing facilities) uneconumie overconsumption of the service will result, i.e., if consumers are not willing to pay as much for the service as the factors devoted to their service could secure elsewhere, they should not be served.

94. The actual price charged is irrelevant. H'illingness to pay, not actual payment, is the significant factor. If there were no divergence between the two, an "allocation policy" would be superfluous; the allocative function would be fulfilled by prices.

95. I.e., the transmission facilities are used a higher percentage of the time, thus spreading the fixed costs over more units of product. Cf. note 72 supro.

96. As is evidenced by the use of natural gas for these purposes in many areas where domestic space heating is provided by other cheaper fuels.

97. See $R e$ South Ga. Natural Gas Co., FPC Press Release No. 6651, G-3067 (1953) ; Re Commonwealth Natural Gas Corp., 9 F.P.C. 70 (1950). In each case the Commission prohibited boiler fuel service although the cost and revenue evidence sultmitted indicated such denial would raise prices to other consumers. Cf. note 72 sufro. 
The allocation pattern of a perfectly competitive private market may itself be criticized on social grounds. The valuation placed on products by private markets may inadequately represent their social value. Costs or values of various fuels, or of different uses of natural gas, or of gas consumption in various locations, may be over- or under-valued by private markets. ${ }^{08}$ Arguments for artifically restricting gas to certain uses, or to use in certain areas, or for the protection of the coal industry have their roots in this sort of reasoning. We shall consider each of these arguments as employed in FPC certification proceedings.

Most discussions of end-use control appear to rest on an intuitive assumption that some uses of gas are inherently "superior" to others, independent of consumer valuations, so that the prices consumers are willing to pay inadequately reflect this superiority. Such discussions tend to ignore the economic costs of restrictions on use, and the limitation on the value to consumers of natural gas even in "superior" uses. If "inferior" users are denied gas and must turn to higher cost alternative resources, that higher cost will be reflected in the price the consumer pays for the output of these other users. The real cost of supplying gas to domestic consumers, for example, must be measured by the value of the gas to the production of alternate products. If consumers offer to pay enough for these other products to enable their producers profitably to bid gas away from domestic consumers, it is an indication that the consumers prefer to have the gas used for industrial purposes. When the demand for both uses comes from domestic consumers, one directly and the other indirectly, it is reasonable to assume that consumers are competent to make their own choice. ${ }^{10}$

The personal convenience of using gas for domestic purposes has apparently convinced some proponents of end-use control that consumer demand for gas for domestic purposes is almost infinite, and that relative costs of different fuels are therefore unimportant. But until recently consumers in many areas did not value gas over coal for space heating greatly enough to be willing to pay the higher price for it. Only as the spread between the prices of the two fuels narrowed, did many consumers convert from coal to gas. ${ }^{100}$

98. This is the traditional argument of social costs vs. private costs and social bencfits vs. private benefits, with which the literature of socialism abounds. See, c.g., LANGt: \& TAylor, op. cit. supra note 91, at 103-08. See also Kapp, THE Soctal Costs of Fr14 vate Enterprise (1950); Clark, Social Control of Business 156-60 (1939). The same arguments are, of course, the basis for much (if not most) of the cconomic regulation in the United States today:

99. Perhaps the greatest advantage of a price system is that such choices are accomplished automatically through consumers' and producers' reactions to the price of factors of production and of products. See Schumpeter, The Nalure and Necessity of a Price System, in Econonic Reconstruction 170-76 (1934).

100. Convenience, cleanliness, and controllability of gas are often and properly cited as reasons for domestic and commercial preference for gas over coal. These advantages cannot be denied but their value to consumers is definite and can be measured with a workable degree of accuracy by the amounts consumers will pay for gas as replacement 
There is one notable exception to the general proposition that the social values of various uses of natural gas-or any other resource ${ }^{101}$-do not differ greatly from the valuations of the private competitive market. The social value of national defense uses of a resource may not be accurately represented by private market valuations, because, in times when national defense is paramount, the private market is to a large extent superseded by a system of priorities based on materials allocation, price control, and rationing. The price which the government offers for resources may not adequately mirror their social value. Hence a private producer cannot expect to receive a price for his gas equal to the cost to him of withholding his supply from alternative markets. There may therefore be inadequate incentive for the private producer to allocate gas to present or future defense requirements.

Present defense needs for natural gas can easily be satisfied from present production. But what of the future? In the interests of conserving natural gas for this "superior" use the government might employ a broad and rather unselective policy of restricting the aggregate rate of production of the resource, on the theory that the gas which is saved will at least include those volumes required for future defense. Alternatively, it might in effect stockpile a supply of natural gas by buying up reserves. This method is currently being applied to some strategic materials, but natural gas is no more vital to defense than are all other fuels. The national defense problems of the supply of natural gas concern the supply systcm, i.c., transmission lines, more than the physical supply of the resource in the ground. The FPC correctly grants defense needs priority over other users on current supplies of gas. If the Defense Department believes in addition that a long run guaranteed supply is necessary, it can secure this more easily by buying up gas reserves located near the transmission lines supplying defense facilities than by curtailing the aggregate rate of consumption.

What of the claim that the expansion of natural gas consumption should be retarded to protect the coal industry, because the social cost of the transfer from coal to gas exceeds the net benefit derived? In the light of the in-

for coal. The demand for gas is not perfectly inelastic Besides consumer valustions, a second limit on the economic value of natural gas is the cost of supplying the same service (e.g., manufactured gas of comparable heat content) with other resources (c.t]., coal). In no use could its value exceed this cost of replacing it with other resources.

101. We are, in fact, arguing that the problems of "conservation" are basically no different from the problem of the best allocation of any other resource and that attempts to consider natural resources as something unique serve only to confuse the issue. In essence the problem of optimum allocation of natural gas is identical in most respects to that of any other product or economic resource when inflexible prices prevent free equation of the amounts supplied and demanded. For example, war produces allocation problems for most products, which are then distributed according to a schedule of social priorities established by public agencies. Whatever the prices to be charged, i.c., whatever the policy of income distribution between consumers and producers, the allocafion of the product should ordinarily follow the allocative principles of a competitive price system. 
roads in fuel markets made by natural gas, ${ }^{102}$ and the long-standing congressional policy protecting coal as a "sick" industry, ${ }^{103}$ a policy restricting free competition between coal and gas might be defended. However, two qualifications must be noted: first, a policy of reduced natural gas consumption admits of little flexibility. The coal industry does not suggest that the government alternately enforce and relax its policy as general business conditions and the demand for coal change. It would in fact be uneconomic to do so, for the high fixed costs of natural gas production and distribution can be justified only if demand for the product will continue rather consistently over a considerable period of time. And second, if the coal inclustry wishes to emphasize the long-run aspects of the impact of natural gas on the coal industry, it will be faced with the necessity of justifying government impediments to the operation of consumer choice. ${ }^{104}$ Whether the advantages of the use of natural gas outweigh any social costs inflicted on the coal industry can be decided only by personal value judgments, and the case for restriction has not yet been proved. In the absence of specific congressional instructions, the FPC has no doubt wisely resisted the petitions of the coal industry.

The same conclusion applies, mutatis mutandis, to the argument for regional or state priorities in the use of gas. The sacial costs of whatever deprivation of gas the producing states might suffer can be only vaguely compared with the benefits the consuming areas receive. If a value judgment is to be made, Congress seems the proper agency to make it.

A second general argument for restrictions on the use of natural gas reasons that private exploitation of natural resources is too rapid, and results in present waste at the cost of future deprivation because private markets overvalue present consumption and undervalue future use. ${ }^{105}$ Should we then save gas for future use by restricting the current rate of consumption? A full answer to this question is beyond the scope of this article but certain aspects of the problem should be noted.

102. See [1950] Statistical Abstract of the United States 469.

103. Articulated in the Bituminous Coal Code of the NRA and the extension of its general provisions in the Guffey Acts of 1935 and 1937. The NRA and the Guffey Act of 1935 were declared unconstitutional. Schechter v. United States, 295 U.S. 495 (1935); Carter v. Carter Coal Co., 298 U.S. 238 (1936). The Guffey Act of 1937 expired in 1941 and was not renewed. On this and other aspects of the industry, see Leonard, The Bituminous Coal Industry, in The Strtcture of the Adericax Economy c. 2 (Adams ed. 1950).

104. Cf. Troxel, op. cit. supra note 93, at 211: "[T] hese interests are concerned with coal production and transportation, not with wise conservation and economical utilization of the scarce resources of the nation. Trying to preserve the prodluction of coal, the value of coal mine investments, railroad revenue, and the jobs of coal mincrs, they are willing to obstruct the use of a new and more economical fuel."

105. See Pigou, Economics of Welfare 29-30 (1932); Stocking \& Watkins, Cartels or Competition? 313 (1948); Gray, Economic Possibilitics of Conservation, 27 Q.J. Econ. 499 (1913). 
First, it costs money to save gas. Gas used now can free another resource for productive use. ${ }^{106}$ Gas should therefore be used now unless its future value is expected to exceed its present value by more than the aggregate productivity, throughout the entire waiting period, of the resource freed by the use of natural gas. To ignore the rate of interest and the productivity of investment is as uneconomic as it is unprofitable.

Second, the possibilities that the future will produce alternatives to the present gas supply, including new supplies of gas, atomic, and solar energy, and synthetic production of gas from coal, are considerable. The alternative to present use may be non-use.

Third, even assuming that the argument for general restriction is valid, the proper allocation policy for the FPC to follow would be identical to that explained above: allot gas to those consumers willing to pay the greatest amount in excess of the cost of supplying them. Even if the FPC followed the rate policy most liberal to producers, and allowed them revenues sufficient to cover present replacement costs rather than historical cost, the price of gas would still not be high enough to cover this added "social value" factor. Perhaps the simplest device for achieving optimum allocation under these conditions would be to impose a tax on the use of natural gas, designed to represent the difference between the current market price of the gas and its higher social value. Under a unit tax producers would service those customers willing to pay the most in excess of the costs of supply, rather than those who use the resource for some alleged "socially superior" purpose.

Fourth, the issue of restricting the aggregate rate of use involves allocation over time, while the FPC to date has been almost exclusively concerned with short-term, temporary policies to bridge the gap until transmission facilities are available to transport additional supplies to markets.

Finally, and as a summary comment for the entire discussion, it is important to note that the allocation criteria developed by the Commission apply more to the use of pipeline capacity than to the consumption of natural gas itself. The FPC has thus not faced directly the broader problems of allocation of the nation's aggregate natural gas supply, and has shown little inclination to do so. This is primarily due to the essentially negative role the

106. The use of a natural resource means that other resources, of a like value, are freed for investment in productive enterprises. The return on this investment, then, is legitimately assignable to the natural resource, the use of which made the investment possible. The use of a natural resource is equivalent to reduction in consumption, which similarly frees resources for productive investment.

A major qualification should be noted: the above analysis is valid only under full employment conditions. If resources are not fully employed, the use of a natural resource will free resources, an excess of which already exists. No productivity cuuld therefore be attributed to the natural resource in this case. This analytical defect is unfortunately typical of the whole of conservation theory. Its impurtance is perhaps restricted in any long-run analysis, and FPC allocations of gas are intended to provide for permanent services to consuming areas. The problem of the pruper FPC cyclical policy is a topic far beyond the limits of this article. 
Commission fills. The initiation of pipeline projects is accomplished by private companies; the Commission exercises little more than a veto power. By its very requirement that certificate applicants submit evidence of adequate reserves of natural gas, ${ }^{107}$ the Commission has avoided the problem of allocation of gas reserves, which are claimed on a first-come, first-served basis. The Commission has revealed its allocation proclivities when forced in certification cases to decide between rival applicants for service, but the major allocation of reserves remains a function of the companies themselves and the private market. In the absence of congressional determination of allocation policy, and considering the difficulty of establishing a schedule of social priorities, this must be considered fortunate.

107. FPC, The First Five Years Under the Natural. Gas Act, Report to tile Committee on Interstate \& Foreign Conmerce 19 (1944); Re United Gas Pipe Line Co., 10 F.P.C. 35 (1951); $R e$ Texas Gas Transmission Corp., 8 F.P.C. 190 (1949); Atlantic Seaboard Corp., 7 F.P.C. 926 (1948). 